\title{
Small State Anti-Fascism: Norway's Quest to Eliminate the Franco Regime in the Aftermath of World War II
}

\author{
Helge Øystein Pharo \\ Professor of International History Emeritus. University of Oslo. Home Adr. Bertrand Narvesens vei 3, 0661 Oslo, Norway. \\ e-mail: helge.pharo@iakh.uio.no \\ ORCID iD: http://orcid.org/0000-0001-5251-1118
}

Submitted: 9 January 2017. Accepted: 20 January 2017

\begin{abstract}
In the early postwar years Norway was among the most active in the campaign against Franco's Spain, supporting the policy of keeping Spain out of the UN, and pushing for UN members to break off diplomatic relations with Spain. Within a few years the policy of ostracism was seen to fail as it appeared to strengthen rather than weaken the Franco regime. Spain was then gradually allowed into the warmth. Until the early 1950s Norway's retreat from its 1946 position was very reluctant, and it was in 1949 the last Western European state to accept normalization. Spain retaliated with economic pressures, and by 1951 Norway had relented and joined in the general reestablishment of normal diplomatic relations, and in 1955 accepted the package deal that brought Spain into the UN. The article discusses the foreign policy concerns and the domestic political struggles that explain Norwegian policies, including the veto on Spanish NATO membership that was never given up.
\end{abstract}

KEYWORDS: Norwegian foreign policy; Universality and UN membership; Isolation of Franco Spain; NATO membership; Diplomatic relations; Trade war; Small state activism; Anti-Fascism.

Citation / Cómo citar este artículo: Pharo, Helge (2018) "Small State Anti-Fascism: Norway’s Quest to Eliminate the Franco Regime in the Aftermath of World War II". Culture \& History Digital Journal, 7 (1): e008. https://doi.org/10.3989/ chdj.2018.008

RESUMEN: Antifascismo de pequeño Estado: el objetivo de Noruega de eliminar el régimen de Franco como consecuencia de la Segunda Guerra Mundial.- En los primeros años de la posguerra Noruega fue uno de los países más activos en la campaña en contra de la España de Franco, apoyando la política de apartar a España fuera de las Naciones Unidas y presionando a los miembros de ésta a romper las relaciones diplomáticas con ella. En unos pocos años se comprobó el fracaso de la política del ostracismo, puesto que acabó por fortalecer, más que debilitar, el régimen franquista. A partir de entonces, las relaciones con España fueron templándose poco a poco. Hasta los primeros años cincuenta, la retractación noruega de su posición de 1946 resultó un tanto reacia, y no fue hasta 1949 cuando se convirtió en el último de los estados de Europa occidental en aceptar la normalización de la situación. España contraatacó con presiones económicas y para 1951 Noruega ya había cedido su posición para unirse al restablecimiento general de las relaciones diplomáticas normales, de manera que en 1955 aceptó el paquete de acuerdos que llevó a España a las Naciones Unidas. Este artículo analiza las relaciones internacionales y las luchas políticas domésticas que explican las políticas noruegas, incluyendo el veto al ingreso de España como miembro de la OTAN, que nunca fue levantado.

PALABRAS CLAVE: Política exterior noruega; Universalidad y membresía de Naciones Unidas; Aislamiento de la España de Franco; Membresía de la OTAN; Relaciones diplomáticas; Guerra comercial; Activismo de pequeño Estado; Antifascismo.

Copyright: (C) 2018 CSIC. This is an open-access article distributed under the terms of the Creative Commons Attribution 4.0 International (CC BY 4.0) License. 
Norway's short lived crusade to topple the Franco regime after World War II bears witness to the enduring strength of broadly based sympathies for the republican forces in Spain during the Civil War. These sympathies were particularly strong within the ruling Labor Party and among the Communists and translated into efforts to have the United Nations isolate the Franco regime with the eventual goal of removing it. Within less than a year of the start of the crusade in 1946 Norway had to beat a rather ungraceful retreat. The process is analyzed within the context of the evolution of Norwegian foreign policy in the aftermath of the World War, and the domestic struggles over the direction of foreign policy that were intimately linked to the struggle for supremacy within the Labor movement. While anti-Franco sentiments were strong, Norwegian economic interests suffered as a consequence of the campaign. To what extent did economics matter when Norway shelved its campaign? The transformation of Norway's Spanish policies were certainly affected by the passing of time and the firmly held belief of the Labor Government, and Foreign Minister Halvard M. Lange in particular, that the United Nations was to be a universal organization. In the long run it turned out, not even Spain could be ostracized.

We shall first look briefly at Norway's foreign policy predicaments in the period of transition from War to Cold War, then move on to the deliberations, cabals and horsetrading at the United Nations regarding the Franco regime until the early 1950s. Then we shall look more closely at the bilateral relations and the domestic struggles over Norway's position on Spain in international organizations up to the mid 1950s. ${ }^{1}$

\section{THE NORWEGIAN FOREIGN POLICY TRADITION}

Norway peacefully left the dual kingdom of Norway and Sweden in 1905, thus gaining complete sovereignty also in matters of foreign policy. The newly sovereign state declared its intention to stay out of entanglements with the European warrior states and to diligently pursue its foreign economic interests. Norway tried to have its neutrality guaranteed by the great powers. As that was not to be, Norwegian governments until the German surprise attack of April 1940, based their foreign and security policies on the assumption that the country's sovereignty and territorial integrity would be taken care of by an implicit British guarantee. As the Norwegians saw it, Britain would not tolerate another great power taking control of Norway, and British control of the adjoining seas would make it impossible for any such power to do so. Thus Norway would enjoy sovereignty and protection with minimal military effort of her own (Riste, 2005: 69-153). During World War I Norway stayed neutral, but pursued such a pro-British policy that the author of the standard work titled it: Norway: the Neutral Ally (Riste, 1965).

Norway joined the League of Nations rather reluctantly and with considerable domestic opposition both from the socialists on the left and from the strongly nationalist right. Yet, as Britain was the key member of the League, successive Norwegian governments decided that Norway needed to join and stay in for both economic and security reasons (Fure, 1996: 181-185). However, Norway was not an enthusiastic member, did not commit itself to the military sanctions clause and only reluctantly to the economic one. For all practical purposes Norway withdrew from the League after 1936. Internationalism of a legalistic kind characterized its policies, in addition to occasional small state activism, but essentially Norway chose exit over loyalty when push came to shove. Isolationism, neutralism and skepticism of the great powers remained staples of foreign policy debates (Fure, 1996: 181-214; Riste, 2005: 129-137). The belief in the implicit British guarantee was not due to any trust in British altruism, but was, as mentioned, founded on the assumption that Britain in its own interest would keep other states away. The Norwegians on the basis of their experiences in the Napoleonic Wars and World War I realized that in the last resort they could not afford to be aligned with the opponents of Britain.

The German attack on 9 April 1940 made for a rude awakening. The British fleet proved to be neither a deterrent nor a significant obstacle to the Germans. The two months long campaign proved a disaster for the Norwegians and the allied expeditionary forces. The lesson learnt by the smallish foreign policy elite was that the implicit British guarantee was insufficient to maintain Norway's sovereignty and territorial integrity, and that outside support for the defense of the realm had to be prepared in peace time (Riste, 2005: 138-153; Sverdrup, 1996: 15-61). As a consequence, by 1941 the Norwegian government-in-exile in London had placed itself firmly in the allied camp and turned into an avid supporter of a postwar North Atlantic alliance system. Isolationism of the interwar brand was given up, and neutrality was no longer an option for Norway (Riste, 2005: 154-169; Sverdrup, 1996: 83-98).

When in 1944 the Americans made clear that such a system would not be compatible with the United Nations scheme, the British decided they had to fall in line with the Americans and at least for the time being abandon their North Atlantic plans. On their own they would not have the capability to protect Norway against another future continental predator, be it Germany or the Soviet Union. The exile government then replaced western alignment with bridge-building, though without quite realizing how the war had undermined British power.

The move to bridge-building was also prompted by the reemergence of the Soviet Union as the major power bordering on Norway, a liberator of the northernmost county from German occupation, and a claimant for what amounted to a condominium of Spitsbergen. In this situation the exile government, and its successor Labor governments after the end of the war, decided to trust the United Nations to uphold Norway's sovereignty and territorial integrity. Such a change of policy presupposed that the allied great powers that created the United Nations would be able to maintain a minimum of coopera- 
tion after the war, so that the Security Council would not be immobilized by the veto, making the UN unable to protect its member states. Norwegian foreign policy makers were perfectly aware of the possibility that the great powers might fall out. Bridge-building was tailored to help keep the former allies on friendly terms. Norway could at least chip in by not being seen to take side in East-West confrontations. If tension between the former allies nevertheless reached the point where war might be seen to threaten, Norway would seek a security guarantee from the Anglo-American powers. Thus bridge-building was conditional, and approaching the Western powers to ask for protection constituted the government's reserve position. A majority of Norwegians, parliamentarians in particular, were most likely in no doubt who the potential protectors would be, even if they were ignorant of the reserve position. After the Americans launched the Marshall Plan, and in particular after the Communist coup in Prague and Moscow's alliance proposal to Finland in February of 1948 , and rumors of a similar proposal to Norway, the Labor government started exploring the Western option (Sverdrup, 1996: 201-234, 277-302; Riste, 2005: 173-177, 192-205; Pharo, 1976, 2014).

Bridge-building was not merely a means to stay out of great power confrontations and thus help keeping them on acceptably good terms, it crucially also represented a road to a domestic foreign policy consensus. The Communists and the Labor Party left wing were strongly critical of the capitalist West and the United States in particular. Main stream Labor was pro-British and admired Clement Attlee's Labor government, but was also critical of the United States. The center-right parties were less united in their views, but skepticism of the Soviet Union was fairly widespread among the Conservatives, and by late 1946 the newspapers of the center-right parties increasingly carried articles critical of the Soviet Union and the bridge-building policy. By the summer and fall of 1947 the foreign policy consensus was in fact disintegrating, also with regard to the Spanish issue. Tensions were by this time running high, and the Labor government had to handle foreign policy issues with great care as ideological commitments reinforced conflicting views of Norway's security situation and the potential threats against its sovereignty and territory (Pharo, 1989, 2014; Eriksen, 1972).

\section{THE UNITED NATIONS AND THE FRANCO REGIME}

The United States and Britain had of need maintained a somewhat ambiguous relationship with Franco during the War, doing what they could to keep him from taking part in the war on the side of the Axis powers. Spain's entry into the war would obviously constitute a serious threat to the Allied position in the Mediterranean. The Soviet Union entertained no such ambiguities as backers of the Republicans during the Civil War and having been exposed to the atrocities of the Spanish Blue Division on the Eastern Front. By the time the Allied powers founded the United Nations at the 1945 San Francisco conference, the
US and Britain had moved closer to the Soviet position. According to a resolution proposed by Mexico the UN would be closed both to the former Axis powers and any regime brought to power with the help of the armed forces of these powers (Luard, 1982: 361; Russel, 1959: 844845). The resolution was explicitly intended to keep Spain out until the Franco regime had been replaced, and was passed unanimously. Thus began the campaign against the Franco regime within the United Nations. The Big Three followed up in the Potsdam Communique of 2 August 1945:

The Three Governments feel bound however, to make it clear that they for their part would not favor any application for membership [in the UN] put forward by the present Spanish Government, which, having been founded with the support of the Axis Powers, does not, in view of its origins, its nature, its record and its close association with the aggressor States, possess the qualifications necessary to justify such membership (FRUS, 1945, 2: 1510).

The campaign to ostracize Spain reached new heights in early 1946, even as we can discern the beginning of its decline at the same time. Though the activists -individuals, organizations and governments- did not realize it, the campaign's zenith was passed during the first few months of the year. In March the US, Britain and France issued a joint statement that expressed the hope that the Spanish people would find the means to bring about the peaceful withdrawal of Franco, and be able freely to choose their own leaders. They added, however, the caveat that they hoped this could be achieved without again subjecting the Spanish people "to the horrors and bitterness of civil strife" (Botero, 2001: 115). As they were stepping up the pressure the Western great powers were also having second thoughts. The Franco government was showing considerable resilience in the face of isolation and international pressures. The Americans and the British were both concerned that they should not contribute to a resumption of the civil war, and they were worried that only the Soviet Union would benefit if that happened. Thus they objected to a French proposal in late March of 1946 to impose a gasoline embargo and cut off all trade relations with Spain (Botero, 2001: 116).

As the Americans and the British were having second thoughts regarding punitive measures against Spain, and relations with the Soviet Union deteriorated as a consequence of disagreements over the peace treaties with the former Axis satellites and as a result of Soviet claims on Turkey and Iran, the states pushing the campaign against Franco gained only modest victories in the UN during 1946. General Assembly Resolution 32 of 9 February reaffirmed Spain's ineligibility for membership. Resolution 39 of 12 December excluded the Franco Government from membership in any international agency related to the UN, and furthermore recommended that all member states recall their accredited ambassadors and ministers plenipotentiary from Madrid. With the exception of Ar- 
gentina, Portugal and the Vatican support for the resolution was universal (Botero, 2001: 116). Yet the December resolution also signified that the campaign against Franco was running out of steam. What eventually passed was a watered down version of what the Eastern Bloc and the activist Western states had wanted. The process leading to the resolution was exceedingly complex and confusing, but the Americans and the British eventually side-tracked a proposal that called for the termination of diplomatic relations between Spain and the member states of the UN (Botero, 2001: 115-116; Haraldstad, 1994: 44-475' Shipulina, 2013: 22-32).

Between February and December 1946 the Americans and the British were on the one hand becoming increasingly worried by the economic situation in Spain, and on the other feared that outside pressures would merely strengthen Franco's position as he would appeal to Spanish nationalism. They were also becoming convinced that no viable alternative to Franco existed, and that the outbreak of another civil war would completely exhaust the country. From Moscow George Kennan's analyses of Soviet perceptions of the situation in Spain increased US worries and strengthened the determination not to support the more far-reaching proposals by Eastern bloc countries such as Poland and by western European activists such as Belgium and Norway. In Kennan's view, the Soviets saw the situation in Spain as ripe for revolution, and consequently providing an opening for an expansion of Soviet influence in the western Mediterranean. At the same time support for the harsh anti-Franco posture was waning in the United States (FRUS, 1946, 5: 1033-1036; Botero, 2001: 115-118).

Norway did not play a prominent role in the process leading to Resolution 32 in February, though Foreign Minister Lange, when reporting from the UN General Assembly in Parliament, claimed that the delegation had successfully pushed for a sharpening of the language (St.t. 1945-1946: 296). However, leading up to the fall General Assembly and the December Resolution 39, the Foreign Ministry and the UN delegation took a most active part. The basis for this activism on the part of the Norwegian Government may be found in a compound of causes, some of them of an international nature, some of them of domestic origins. Clearly what triggered the Norwegian engagement was the Franco regime's execution of members of the opposition in February, which to Norwegian activists brought back vivid memories of the Civil War and gave the pro-Republican forces a vitamin injection (Benum, 1969: 13-17). We shall return more fully to the domestic setting, and only look briefly into it at this point. We must also at this point take note of the fact that the anti-Franco campaign within the Storting as well as in the country at large was coordinated by the Spain Committee. It had been created during the Civil War and was resurrected in 1945 as a consequence of a Trade Union Council initiative. The Committee counted among its members prominent Labor parliamentarians (Benum, 1969; Haraldstad, 1994).

Subsequent to the passing of Resolution 32 Lange informed the Storting of the international status of the
Spanish problem. The Communists and the Labor left pushed hard for a more uncompromising Norwegian approach than had been on display in February, which the government only with difficulty was able to modify. On 6 March 1946 the Storting passed the following resolution:

The Storting hereby expresses its most earnest sympathy for the liberation struggle of the Spanish people. The Storting is fully confident that the cabinet will maintain close contact with the Storting and its subordinate parts with regard to this issue, in order that Norway may fully do its duty as a democratic state in an inter-allied effort to reestablish democracy in Spain (St.t., 1945-1946: 300).

The Storting resolution is notable for three reasons. In the first place the left wing critics of the Franco regime were clearly in doubt whether the Government would actually pursue a consistent anti-Franco policy in the UN as well as bilaterally, and wanted to nail the Government to the pursuit of such a policy. Secondly, the resolution marked the beginning of the activist phase of Norwegian policy with regard to Spain, in both arenas. Thirdly, the Government, and Lange in particular, were well aware that in a duel with Spain Norway was the weaker part unless it was part of a unified Western coalition. Thus the phrase "interallied effort" was included. Lange and the Cabinet were not willing to commit Norway to a lone confrontation that Norway was bound to lose (Haraldstad, 1994: 43-44; Sverdrup, 1996: 246). In retrospect it may appear something of an anomaly that Norway was willing to join with the Soviet Union and its satellites and part ways with the West. However, during the early postwar years such an alignment in an individual case was seen as a most appropriate expression of bridge-building. It might enhance the credibility of bridge-building to the Soviets, while not alienating the West. While Lange and the Cabinet knew Norway's protectors would probably disapprove, Spain's UN membership did not represent a crucial case in the emerging Cold War. However, as the Cold War fronts froze, such attempts at bridge-building would satisfy none of the antagonists (Mordt, 2003: 177; Pharo, 1976, 2014).

By the summer of 1946 Norway was pushing for much harsher measures against Spain within the framework of the UN. Rumors in the press and the diplomatic grapevine had it that Britain and France were contemplating action against Franco. France was certainly pushing for action in the spring of 1946 without much to show for it, but by the time Lange met with Prime Minister Attlee in the summer of that year he was told in no uncertain terms that the British and the Americans were reluctant to support more punitive measures and feared that increased pressure might destabilize Spain. In their opinion there really were no credible alternatives to Franco. Pressure against Franco in fact appeared to strengthen rather than weaken him (Haraldstad, 1994: 44-48; Shipulina, 2013: 28-29; Benum, 1969: 16-17; Sverdrup, 1996: 246-247).

During the fall of 1946 the Norwegians maintained their efforts to have the Spanish case discussed by the Gen- 
eral Assembly, and kept in contact with likeminded nations such as France, Belgium and Czechoslovakia, the latter being seen as Norway's bridge-building counterpart in the East. Lange and the Cabinet were motivated by a mix of parliamentary pressure and their own deeply rooted disgust with the Franco regime as they were searching for a way to have diplomatic relations terminated by the UN members (Shipulina, 2013: 29; Sverdrup, 1996: 246-247). As we have seen, primarily due to US opposition the final text of Resolution 39 fell far short of that goal, even if it was more radical than what the Americans had wanted. While Lange and the Foreign Ministry had worked loyally according to the Storting resolution, the Foreign Minister in retrospect was clearly relieved that diplomatic relations with Spain were to be down-graded rather than broken off. The escape clause of the March Storting resolution provided adequate cover for the Foreign Minister, who in February 1947 further modified the Norwegian position: "...that we within the framework of the United Nations would contribute to support a united effort that might lead to the reestablishment of democracy in Spain" (Haraldstad, 1994: 43-45).

On the way to Resolution 39 Norway had proposed a modified version of the Polish proposal to break off diplomatic relations. Member states were to notify the Secretary General by 16 January 1947 whether they were willing to break off diplomatic relations with Spain, or whether in fact they did not have such relations. If two thirds of the member states had done so, the Secretary General should ask the states willing to do so to terminate relations. If less than two thirds of the members had expressed such willingness, the Secretary General should inform those that were willing that they were at liberty to do so (St. meld. 36, 1947: 19; Shipulina, 2013: 30-32). We have as yet not uncovered any evidence on what Lange and the Foreign Ministry thought of the prospects for success for this rather complicated proposal. We may, until possibly contradictory evidence becomes available, conclude that it was a face-saving proposal intended to keep the Storting happy. Eventually the watered-down version, to down-grade diplomatic relations and not allow Spain to become a member of affiliated organizations, was passed by a vote of 34 against 6 . The US and Great Britain also voted yes (Shipulina, 2013: 30-32; St.meld. 12, 1947: 20).

From then on the Spanish issue in the UN became the object of a tug-of-war between those states that wanted to confirm the December 1946 resolution and the growing number of states that worked to have the resolution revoked. In 1947 a proposal to confirm the 1946 resolution failed to gain a two thirds majority in the General Assembly, and in 1949 a proposal to revoke Resolution 39 failed by one vote to gain a two thirds majority. Norway was the only state in Western Europe and the Americas to oppose the proposal, and in a sense cast the decisive no vote by going along with the Soviet bloc (Shipulina, 2013: 33-38; Haraldstad, 1994: 46-47). The following year the General Assembly revoked Resolution 39 by a vote of 37 in favour, 10 against and 12 abstaining. The Soviet bloc uniformly voted against, while on this occasion no Western democracy joined them. Britain, France and the Scandianvian countries were among those abstaining, while the United States voted yes (Haraldstad, 1994: 58). Within a short while the heads of mission returned to Madrid, Rolf Andersen for Norway in 1951 .

At the same time as the heads of mission reassembled in Madrid, Spain gained entry to a number of UN affiliated agencies, starting with the Food and Agricultural Organization in 1950, then the International Postal Union, the World Health Organization and the International Civil Aviation Organization in 1951. None of these memberships caused any Norwegian protests or even misgivings. When the issue of Spanish membership in the United Nations Educational, Scientific, and Cultural Organization was tabled in May 1952, however, the strength of the antiFranco forces in Norway again proved itself. Lange brought the membership matter to the attention of the Cabinet. His colleagues agreed that Norway should voice no objections to Spanish membership. Before long, however, the opposition took to the field. The Spain committee was joined by the Trade Union Council and Labor's youth movement in opposition. The youth movement frequently opposed Labor's foreign policy during the Cold War.

When the Swedes indicated that they would abstain, the Labor government eventually decided to join forces with their social democratic kin, to the chagrin of Spain which feared that the Scandinavian abstentions might prove decisive in blocking membership. The Spanish Government again threatened to bring sanctions to bear on Norway, as they had done repeatedly from 1947 onwards, and the Norwegian embassy transmitted regrets over the negative Norwegian stance, which in their opinion brought to naught their efforts over the preceding year to improve relations (Haraldstad, 1994: 59-60).

Within three years Spain would be admitted to the United Nations as part of an extensive package deal that admitted a large number of both pro-Western and Communist countries in a balanced way. As the allies turned bitter rivals soon after the end of the war, they also increasingly diverged on the criteria for UN membership. Deadlocks over membership proposals ensued, and the process leading to the package deal was both slow and laborious (Luard, 1982: 361-372). Norway welcomed the package deal and offered no objections to Spanish membership. Even the Spain Committee did not object to what in retrospect appears a rather dramatic change of course. Haraldstad explains this remarkable change by assuming that Norwegian public opinion, and that would include the Spain Committee and its followers, had gradually come to accept the universality principle with regard to UN membership (Haraldstad, 1994: 69-74). However, the universality principle had been part and parcel of Norwegian UN policies since 1945, Spain and the former Axis satellites represented the exceptions to the rule. That, of course, may not invalidate Haraldstad's argument. Her point is that public opinion, not the Cabinet nor the Foreign Ministry, had changed course with regard to the principle. That is certainly conceivable, but she provides no direct evidence for her conclusion. She merely points 
to the assumed shift in public opinion and the disappearance of lobby groups and parliamentary pressures. Whatever the merit of the universality argument, we obviously have to look further for a satisfactory explanation, and at least try to sort out why universality made such an impact on an issue that was certainly more important than UNESCO membership a mere three years earlier.

The Norwegian retreat must partly be explained in terms of the sheer futility of the process of ostracism. There was never a two thirds majority in the General Assembly that wanted to break off diplomatic relations. Furthermore the half-measures that were carried were seen to consolidate the Franco regime rather than weaken it. The United States moved from supporter to opponent of anti-Franco measures within two years of the end of the war. By the fall of 1947 the State Department and the President had come to share George Kennan's analysis that pointed to the necessity for propping up rather than undermining Franco (Botero, 2001: 117-120; FRUS, 1947, 3: 1091-1095). The Congress and the US military favored including Franco in the Western line-up, i.e. the Marshall Plan and the OEEC as well as NATO. Neither President Harry S. Truman nor Secretary of State Dean Acheson would go along with such proposals in the late 1940s, not the least because they knew that it would antagonize not merely the Northern European Social Democrats but also the British and French Governments. Nevertheless the US first only inched towards including Spain and then, after the outbreak of the Korean War, galloped to bring Spain into the Western system by the Madrid agreements of 1953 on economic aid and defense cooperation. By that time Spain was also invited into the OEEC negotiations on the Green Plan regarding trade in agricultural and other primary sector products (Botero, 2001: 120-166; Haraldstad, 1994: 75-79; Eriksen and Pharo, 1997: 47-49).

Historians have as yet found no indications that the US applied direct pressure on Norway in any of these cases. We may still assume, though, that knowledge of the US positions and of the pressure that Congress, the military and to a degree broader public opinion put on the Truman and later on the Eisenhower administration to bring in Spain, caused the Norwegian Government to have second thoughts about their position on Spain and the United Nations. The Foreign Ministry and the Cabinet were certainly also aware that given the large number of dictatorships/one party states of a fairly unsavory nature that were and would become members, the insistence on keeping Spain out might be considered somewhat as an exhibition of moral and political double standards. By the early 1950s Norwegian critics of the Spanish policy pointed this out with increasing frequency (Haraldstad, 1994: 67-74, 116-124). The fact that Spain gained entry through a package deal may also be part of the explanation for Norway's acquiescence. In the first place, the great power agreement was in perfect harmony with Labor's visions for the future of East-West relations. Secondly, the fact that the deal allowed the entry of a number of people's democracies must have served to silence crit- ics on the left (Eriksen and Pharo, 1997: 15-28, 44-50, 405-417).

Altogether there were a large number of factors pulling in the same direction, and with only modest relevant archival evidence available, we shall probably never be able to sort out which were the most important. Certainly the fact that the memories of World War II and in particular of the Spanish Civil War were fading must be taken into account. The emergence of the Cold War gradually turned Spain from an adversary to a potential ally, at least as seen by the Americans who footed most of the Allied Cold War bill. The outbreak of the war in Korea, and the dismal outlook for the defense of Western Europe in the case of a Soviet onslaught made the peninsula increasingly important. Conceivably more important from the Norwegian point of view, the semi-measures clearly did not work. Seen from the outside they were counter-productive in that Franco's position appeared to be strengthened rather than weakened. Certainly, as long as ostracism was imposed there was no room for Spanish alternatives to develop.

Finn Moe, chairman of the Storting Foreign Relations Committee, former ambassador to the UN, and Lange's rival for the position as Foreign Minister in 1946, was the first leading Labor politician publicly to take issue with the reigning orthodoxy. In a newspaper interview in the summer of 1952 he declared that he held the somewhat heretical opinion "...that I cannot oppose Spanish membership in the UN, which has as its main task the maintenance of peace in the world. It is a goal that would be more easily achieved if all countries were members of the organization. Thus every country ought to be a member." Even if domestic reactions were quite adverse, Moe's point made an impact even on the most committed critics of the Spanish regime (Haraldstad, 1994: 69). In essence, what he said was that in international affairs a bit of pragmatism might be useful when principles only lead to a dead end. For far too long, as Lange's closest adviser Arne Ording put it already in early February of 1947, Spain had been "a matter of religion" (Mordt, 2003: 226).

Moe's comments confirm Haraldstad's thesis with regard to the importance of the universality principle. However, to fully grasp why the principle eventually brought ostracism to an end we need to bear in mind that Labor's leadership already had reached the conclusion that their Spanish policy was most likely counterproductive in terms of Norwegian economic interests, alliance policies, and the functioning of the UN. Even so, on NATO Norwegian governments would not budge. Norway remained staunchly opposed to Spanish membership until after the death of Franco, and because of the unanimity rule was able to keep Spain out (Eriksen and Pharo, 1997: 48-50). The Spanish Government, correctly seeing Norway as the main opponent of membership, rather gleefully pointed to what they considered Norwegian double standards. According to a December 1955 State Department memorandum of conversation: "... it seemed a paradox to the Spaniards that the one nation in NATO which most violently opposed the admission to NATO was also the nation 
which denied the US access to bases on its national territory (Eriksen and Pharo, 1997: 48; FRUS, 1955-1957, 27: 558). Spanish opponents of the regime disagreed, of course. They expressed their [...deeply felt ...] gratitude to the Foreign Ministry of the noble and heroic Norwegian people" (Eriksen and Pharo, 1997: 48).

We shall return to NATO in the concluding section, but first turn to the reasons why the campaign against Franco remained alive and well for so long, despite sustained criticism from powerful Norwegian interests and at the same time declining popular interest in the matter from the late 1940s.

\section{NORWAY AND FRANCO'S SPAIN-A TROUBLED RELATIONSHIP}

The United Nations General Assembly, the committees and the corridors were the locations where the major as well as the minor actors promoted their views and took their positions on whether to blacklist the Franco regime or have it admitted to the international system as a legitimate player. As a fervent believer in the long term importance of the United Nations for the creation of a more just and peaceful world, Norway took its role in the deliberations most seriously with a view to strengthening the organization as well as safeguarding its own interests (Eriksen and Pharo, 1997: 15-28, 405-417; Sverdrup, 1996: 183-198; Riste, 2005: 183-185). The deliberations at UN headquarters were certainly important for how the Labor Cabinet made up its mind, but even more important were the ones taking place in Oslo. That is where the guidelines for the positions taken in the General Assembly and the committees were constructed. That is where the dilemmas of action or inaction were sorted out as the Cabinet found itself in the cross-fires between the Norwegian pro-Republican advocates, strong and increasingly frustrated economic interests, and growing dissatisfaction on the center-right of the political spectrum and among many ordinary Norwegians. In addition to the tension created by the domestic fault lines, the Franco Government added to tensions and dilemmas by threatening to or actually exerting economic pressure on Norway (Haraldstad, 1994: 43-74; Sverdrup, 1996: 251-256).

Edgeir Benum in his controversial yet much acclaimed M.phil. thesis from 1969 claimed that the Norwegian initiatives and positions taken in the UN were intended to divert attention from what Lange and the Cabinet primarily wanted, i.e. a normalization of relations with Spain (Benum, 1969: 9-12, 47-87, 123-135). His analysis has been subjected to sustained criticism in subsequent years. The extreme version he presented, that the government all the way was looking for ways to recognize Spain, clearly cannot be sustained by the currently available archival evidence, in fact barely by the evidence he himself had at his disposal at the time. Those in Labor's leadership most concerned with the Spanish issue, in addition to Foreign Minister Lange, Prime Minister Einar Gerhardsen and the powerful Secretary General Haakon Lie, were all front line figures in the campaigns against Franco during the Civil War and strongly committed to having Franco replaced by a democratic regime (Mordt, 2003: 224; Sverdrup, 1996: 254-255). Just as the majority of Norwegians after the end of the World War they thought the survival of the Franco regime an anomaly, and were seriously concerned with eradicating the last vestiges of Fascism.

No matter how important the Spanish issue could be made out to be by the left wing foreign policy opposition, as far as the Cabinet was concerned it could not be allowed to trump the more vital tasks of reconstruction and economic modernization. For the purpose of rebuilding and developing the Norwegian economy, extremely trade dependent, Norway also relied on imports from Spain: zinc for the metallurgical industry, phosphates for agriculture and salt for the fisheries. Key Norwegian exporters were dependent upon the Spanish market, those of dried and salted cod and paper and pulp in particular. Furthermore, in shipping Norway was a major cross-trader and Spanish ports of call were vital in particular for those ships plying the Mediterranean. ${ }^{2}$ Lange, as was also the case with his predecessor Trygve Lie, who had recently been appointed the first Secretary-General of the United Nations, was acutely aware that Norway was in an extremely weak position if Franco decided to employ economic pressure. Accordingly the Cabinet was disinclined to risk any sort of action that would land the country in a solitary position or in a position where Norway parted ways with all the other Western democracies. Such was the political context for Norwegian support for the threepower declaration of the United States, Great Britain and France in the spring of 1946 . They saw it as the starting point in a process that might lead to the removal of Franco without the risk of another civil war in Spain and without exposing Norway to the sort of confrontations with Spain that Norway was bound to lose (Sverdrup, 1996: 245-246).

The Cabinet was not, however, allowed smooth sailing by Parliament. The Communists launched their offensive on 6 March, when representative Randulf Dalland posed the following question: "Has the government as yet taken any action with regard to breaking off all relations with Franco-Spain?" (Sverdrup, 1996: 246-248; St.t. 1945-1946: 296-297). The question was obviously intended to put the Labor Government on the spot, and it succeeded quite well. Lange and the Cabinet were well aware that sentiments ran high after the executions in February, and they certainly shared the prevailing popular disgust with Spain. On the other hand, as we have seen, they were convinced that a Norwegian initiative without broad international support had the potential to cause grievous harm to Norwegian reconstruction without in the least hurting Spain.

The Communists were certainly committed to the removal of Franco. Members of the Party identified with the opposition exile government in France; some had fought as volunteers in the Civil War, and among them were athletes who had gone to Spain in 1936 to compete in the workers' Olympics that year. Furthermore the Party 
loyally adhered to the foreign policy positions laid down by Moscow (Stenersen, 1991).

To fully understand the bitterness of this struggle over the Spanish issue and the stakes involved, we need both to keep in mind the struggle over bridge-building and to take a brief look at the history of the Norwegian Labor Movement. In 1921 the Norwegian Labor Party, having taken a sharp turn to the left during World War I, decided to join the Comintern, as the only one of the Western European socialist parties. A split followed immediately. A sizable minority exited and formed the Social Democratic Party. After a brief membership period the Labor Party quit the Comintern in opposition to Moscow's demands for Norwegian subservience. A new minority formed a Norwegian Communist Party and remained in the Comintern, while the more moderate Social Democrats in 1927 merged with the main force, still named the Norwegian Labor Party. The Communists were in the wilderness for the remainder of the interwar period, while Labor, still revolutionary, formed a very short-lived minority government in 1928. In 1935 a far more reformist Labor Party formed another minority government, this time based on a firm labor-farmer compromise that lasted until the German attack in 1940. The interwar Labor government formed the core of the government-in-exile that together with the King and Crown Prince left Norway for London in June 1940 on the cruiser Devonshire (Maurseth, 1987; Pryser, 1987).

After the German capitulation Labor in the early summer of 1945 formed a transitional government led by Einar Gerhardsen who had spent the better part of the war in concentration camp. He kept on a small number of the key members of the exile government, foremost amongst them the Foreign Minister Trygve Lie and the Defense Minister Oscar Torp, party chairman during the interwar period. After the fall elections Labor formed a new government with Gerhardsen continuing as premier, and Trygve Lie staying on as foreign minister until February 1946. Until 1961 Labor enjoyed an absolute majority in the Storting, and stayed in power until 1965 with the support of a leftish splinter party. Thus with the exception of three weeks in 1963, Labor was continuously in power for some 30 years if we include the wartime period. The party was, however, quite frequently rent by a number of fissures over domestic as well as foreign policy issues, and its parliamentary caucus was at times in a state of near rebellion, particularly over foreign policy issues, the Spanish being one of the most controversial and long lasting. ${ }^{3}$

After decades in the wilderness the Communists came out of World War II as a major force in Norwegian politics, due to their resistance activities after Germany attacked the Soviet Union in June of 1941, and also as a consequence of a more general radicalization of Norwegian politics that followed upon the war, and indeed also because of a broadly based admiration and compassion for the Soviet Union's wartime efforts and great suffering. The norwegian-Soviet Friendship Association gained an impressive roster of members, including some very respectable members of the center-right parties and the so- cial, academic and economic elite, spear-headed by Prime Minister Gerhardsen and the Chief Justice of the Supreme Court (Eriksen and Pharo, 1997: 61).

The Communists in 1945 gained just less than 12 per cent of the vote, significantly behind Labor with just over 40 per cent, but nearly in the same League as the Conservatives and the Liberals, the two major center-right parties of the interwar period, and ahead of the other two center-right parties, the Agrarians and the Christian Peoples Party (Bergh, 1987: 12). Labor and the Communists both cooperated and competed, in the trade unions in particular, and for a period in 1945 negotiated over a possible party merger (Christensen, 1970). ${ }^{6}$ Representative Dalland's question in the Storting was not merely intended to bring the government's position out in the open and push it to the left, but was also a move in the struggle with Labor over the voter potential of the left. Dalland's question was furthermore an indication of Communist and Soviet suspicions that Labor was not a trust-worthy bridge-builder. It was no secret that the government-inexile for some time during the war had contemplated a close postwar western alignment (Riste, 2005: 160-170; Sverdrup, 1996: 89-98).

The Communists were fully aware that Labor was far from united on foreign policy issues, either with regard to relations with the western great powers and the Soviet Union, or over how to deal with Franco Spain. The Spain Committee handled relations with Spanish exiles and similar organizations in other countries, and coordinated visits by Spanish exiles, protest marches and demonstrations. It wielded considerable influence both within the Labor Party parliamentary caucus, the trade unions and Labor's youth movement. These were also the bases for the most ardent supporters of bridge-building who were frequently suspicious of the Cabinet as being rather spineless in its pursuit that policy (Eriksen, 1972; Pharo, 1976, 2014).

The Communists then were able to pursue their own goals and those of Moscow with regard to the Franco's regime and at the same time score points in the domestic debate over Norwegian foreign policy. Dalland's question, we may assume, was not least intended to bring out in the open the internal tensions within the Labor Party. They were spot on, and forced the Government to accept a more strongly worded and more binding resolution that would reduce the Cabinet's potential to freely pursue what it conceived as Norway's best interests within the UN. The Communist initiative was picked up by the respected Labor parliamentarian Gustav Natvig-Pedersen, formerly of neutralist and pacifist leanings and soon to be both speaker of the Storting and member of the Norwegian Nobel Committee. Natvig-Pedersen was no maverick leftist who could be bullied or neglected by the party leadership. In 1946 and until late 1947 the Communists could play on mainstream Labor parliamentarians who still harbored the idealist and neutralist sentiments that prevailed in the party in the 1930s. ${ }^{4}$ After the Communists sided with Moscow over the Marshall Plan, they were again out in the cold. Yet the leftish Labor Party for- 
eign policy opposition managed quite well on its own, and remained a thorn in the side of the leadership throughout the Cold War, even if Spain by the mid 1950s was no longer a major symbol for the left opposition.

To understand the Spanish problem in Norwegian foreign policy we do not require access to Spanish archives. The issue had a life of its own in Norway. On the other hand, more extensive access to Spanish archives than was given to Hilde Haraldstad would certainly be helpful in sorting out how Spain saw the Norwegians and the potential costs to respectively Spain and Norway of the confrontational approach chosen. However, while access to Spanish archives would potentially put the Norwegian domestic debates into a broader context, it is not likely to bring us to a different understanding of the Norwegian debate and the decisions of the Labor Cabinet that were made under constant pressure from the foreign policy opposition.

The Norwegian offensive against Spain was first about toppling the Franco regime by means of United Nations resolutions. Whether the activists would have been prepared to propose military action has not been a topic in the historiography. As the plans for a UN force never materialized, this is a moot question. As regime change from late 1946 basically became a non-issue, the struggle between the Franco regime on the one side and the Norwegian government and the opposition factions on the other atrophied into one of symbols and prestige. The Spanish government for good reasons expected to be treated as a legitimate government. It was in indisputable control of its territory, and international disapproval gradually receded. The Labor left opposition as well as the government eventually accepted that the Franco regime was there to stay. By 1950 the government had decided that diplomatic representation on equal terms could not be avoided (Haraldstad, 1994: 15-18).

The 1946 parliamentary resolution was passed at a time when regime change in Spain was still conceivable. By the late summer of 1946 outside action for regime change was highly unlikely. The US and the UK had decided that removing Franco was too risky both in terms of the situation in Spain and because mainly the Soviets stood to gain in such an event. By the spring of 1947 even the Norwegian Labor government had concluded that regime change brought about from the outside was no longer an option. Labor's parliamentary caucus shared that conclusion, but was in no mood to draw the obvious conclusion that normalization of diplomatic and trade relations would be the next step (Haraldstad, 1994: 15-20; Sverdrup, 1996: 246-257).

The two countries had not properly reestablished diplomatic relations after the World War. After the end of the Civil War they maintained diplomatic relations at the level of minister for about a year. In 1940 Spain recalled its representative from German occupied Oslo, while Norway throughout the War maintained a lower level representative in Madrid. The Norwegian minister in Madrid passed away in 1940. In 1946 the Spanish Foreign Minister sought to reestablish diplomatic relations with Nor- way at the level of minister as Spain had already done with Denmark and Sweden. The Spanish initiatives were cold-shouldered by Norway. Norway wanted to limit trade to vital imports and exports, and trade was conducted as private compensatory deals; there was no trade agreement between the two parties, also differently from Denmark and Sweden. The Spanish government found the situation most unsatisfactory on both counts (Sverdrup, 1996: 246-256).

In 1947 Franco seized the initiative and turned the tables on the Norwegians. The Spanish government launched an initiative that ended in the reestablishment of mutual diplomatic relations at the level of minister in 1951, ambassador from 1957, and a formal trade agreement preceded diplomatic relations by a few months. The Spanish campaign was launched in early 1947 by way of two memoranda that were presented to the Norwegian chargé d'affaires in Madrid on respectively 5 January and 11 February. In the first one Spain made the charge that Norway unilaterally restricted trade with Spain, and threatened to close Spanish ports to Norwegian shipping. In the second Spain demanded that Norway accept a chargé d'affaires in Oslo, so it would be represented at the same level as Norway in Madrid (Sverdrup, 1996: 251-252).

The process leading to normalization was long and tortuous, and the intra-party struggles within Labor were fierce. Both issues were discussed at length in the Storting Foreign Relations Committee. Lange and the Cabinet were convinced that they had to accept the Spanish demands for a trade agreement. The Spanish market and shipping services were vital to the Norwegian economy, and Lange pointed out that Norway by this time was the only Western state not to have a trade agreement with Spain. He assumed there was a real danger that the Spanish market might be completely lost. The Cabinet had decided it needed to back down. The Cabinet knew it could muster a parliamentary majority for such a decision, but it did not know whether a majority of their own representatives would vote in favor. After several meetings in the Labor parliamentary caucus and heavy handed pressure by Prime Minister Gerhardsen the opposition caved in. On 22 March the Storting by a vote of 110 against 13, two Labor representatives joined the Communists, agreed to reestablish normal trade relations with Spain (Sverdrup, 1996: 252-253).

The Spanish demand for proper diplomatic relations was more difficult for Lange to accept, even though it was quite obvious that the two issues were linked and that there would be no deal on trade without diplomatic recognition. Lange's reluctance was clearly a matter also of personal disgust, but eventually he concluded that there was no way escaping recognition. The matter was cleared with the Foreign Relations committee in late May 1947 and publicly announced in early June. Adverse reactions were much milder than expected, possibly because the Spanish representative would be based in Copenhagen to begin with. He arrived in Oslo only in the fall of 1947 (Sverdrup, 1996: 253-254). 
However, no trade deal was concluded until 1951. Spain exploited its strengthened position to push for an upgrade of diplomatic relations, and repeatedly threatened to impose economic sanctions. From 1948 Norway was put in the position of suitor for a trade agreement, with concomitant rumblings in the parliamentary Labor Party. Extra-parliamentary forces increasingly joined the fray. In the early stages the most vocal and numerous had been those on the left, the Spain Committee, the dock workers, the Communists and Labor left wingers. From the right shipping interests and exporters certainly also gave voice to their misgivings in the early phases, but in public debate they were largely drowned out. As the potentially disastrous effects of the policy of ostracism became increasingly obvious, the opposition gained strength, guided, funded and gradually organized by the Ship-owners Association. Conservative newspapers joined the chorus criticizing the Labor Government for its lack of realism and the harmful effects on Norwegian economic interests (Haraldstad, 1994: 8-42).

At the same time anti-Franco sentiment, even if waning, remained quite strong, and the activists kept staging anti-Franco events far into the 1950s, when similar organizations in other Western European states had either folded or were in the process of being closed down. After the establishment of diplomatic relations demonstrations were staged outside the Spanish embassy. In 1952 a representative of the Giral exile government was invited to the May Day events in Oslo, and the Spain Committee even tried to put him on the stand together with the Prime Minister. The latter attempt proved a flop, but the antiFranco forces remained quite strong for a remarkably long time, even while Norway gradually normalized relations and accepted Spanish membership also in Western organizations that were not universal in nature (Haraldstad, 1994: 43-98).

Part of the explanation for the sustained opposition is no doubt to be found in another of Arne Ording's diary entries in February of 1947 concerning the revolt of the Labor Party parliamentary caucus upon the issue of how to handle the two Spanish memoranda. He returned to the religious imagery of the previous week quoted above: "The whole mess is motivated by domestic political concerns. Spain has become religion, and all bottled-up dissatisfaction is channeled into this issue." (Mordt, 2003: 228). Dissatisfaction with Norwegian foreign policy on the part of the Labor left remained strong throughout the 1950 s, and in 1961 was the main cause for the founding of the Socialist Peoples Party, mostly made up of Labor left wingers with a few former Communists and independent Socialists thrown in (Kvam jr., 1973).

The Labor leadership eventually, though with considerable regrets, gave up fighting a lost battle, even though rearguard skirmishes took place well into the $1950 \mathrm{~s}$, mostly provoked by the rank and file who took much longer to learn to live with defeat. On one battle field, however, the Norwegians did not yield. Franco's Spain was not to become a NATO member. For a new state to be admitted, all members had to agree. When the final de- cisions on Norwegian membership in NATO were taken in the late winter of 1949 Lange told the Labor parliamentary caucus: "We cannot imagine a socialist country voting in favor of Spanish membership. If we end up standing alone, that is what we will do." (Haraldstad, 1996: 100). His promise was conceivably essential to create an overwhelming Labor majority in favor of taking Norway into NATO. At the same time it clearly communicated his strongly held personal views.

When Spain by the middle of the 1950s expressed increasing interest in NATO membership, strongly supported by the Americans, Lange and Gerhardsen reiterated their positions. On a Foreign Ministry memo discussing Spanish views of their chances of being let in, Lange minuted: "We need to oppose this tooth and claw as long as possible. NATO is something different from the UN and the universality principle does not apply" (Haraldstad, 1996: 111). In an interview with a major left-leaning Norwegian daily, Gerhardsen on 15 July stated:

If there were to be a concrete proposal to include Spain as a member, I assume that it cannot be supported by Norway. In Norway we are of the opinion that NATO will be weakened by Spanish membership. This concern is widely shared by the Storting and the Norwegian people (Haraldstad, 1994: 112).

The Labor government would not yield on the membership issue, and the subsequent center-right government did not change course. Memories of the civil war were certainly important, as was the looming threat that any false step on the Spanish issue would threaten the quite fragile Norwegian foreign policy consensus. Furthermore, for the generation coming of age in the interwar period, the civil war in Spain has been likened to the Vietnam War as a formative experience. The interwar generation dominated Norwegian politics from 1945 to the early 1970s. The way the Spain and NATO issue was handled, of course, also in the end served to strengthen Labor's foreign policy credibility at home, which with German membership in NATO and the transition to massive retaliation as NATO strategy was vital.

We should also introduce more overarching themes that stand out in studies of Norwegian foreign policy. Olav Riste, Geir Lundestad and Rolf Tamnes in a number of works have all pointed to a missionary impulse and a strong moralistic strain in Norwegian foreign policy (Pharo, 2004, 2005, 2014). Without doubt such elements should be taken into consideration, as they frequently do not easily coexist with a realist adaptation to international power relationships. However, not just Labor in power but also Norwegian foreign policy makers more generally have tended to see realism and idealism not as opposites but rather as complementary. In order to maintain a functioning and liberal world order democratic ideals should be observed even if in some cases and in the short run they might appear to undermine the position of the West. Idealism as realism clearly had its shortcomings, Lange realized, and he was probably quite frightened by Ger- 
hardsen's occasional propensity to wishful thinking, entering what Lange must have considered as never-never land. Yet, as far as we can tell in retrospect, Lange never let go of his belief that foreign policy was about moral issues as well, even if by his critics he has mainly been portrayed as an astute NATO chess player.

\section{NOTES}

1 At this stage in my research I rely heavily on two M. phil. theses, Benum (1969) and Haraldstad (1994), an MA thesis, Shipulina (2013), and the 1996 monograph by Sverdrup (1996), vol. 4 in the History of Norwegian Foreign Relations. Most references to the primary sources are through these works and others. The most important archives are those of the Norwegian Ministry of Foreign Affairs, up to 1969 available at the Norwegian National Archives in Oslo. The parliamentary proceedings are very important for this study, Stortingstidende (St.t.), the verbatim record of debates, and the white papers, Stortingsmeldinger (St.meld.) in particular. At the Storting archive the minutes of the Foreign Affairs Committee are available for researchers up to about 1980. This article is also, of course, informed by some 40 years of work on Norwegian foreign relations, including co-authorship of vol. 5 in the History of Norwegian Foreign Relations (Eriksen and Pharo, 1997). Olav Riste chaired the steering committee for this multivolume history, and produced a one volume English version (Riste, 2005). For a historiography of Norwegian foreign relations, see Pharo (2004). All translations from the Norwegian are my own.

2 Haraldstad (1994) provides a very informative overview of the economic relationship. For the linkage between reconstruction and bridge-building, see Pharo (1976).

3 The struggles within the Labor Party and between Labor and the Communists are portrayed in the six volume history of the Labor Movement in Norway. The most relevant in this context are Maurseth (1987) and Bergh (1987), respectively volumes 3 and 5.

4 Eriksen (1972) is still the most comprehensive and incisive analysis of disagreements and struggles on the left over foreign policy issues. See also Pharo (2014). The neutralists and great power sceptics, who constituted the majority in the Labor Party in the interwar period, were by and large pushed on to the sidelines from 1945 onwards. From there the most leftish of them pursued consistent sniper activity. Most of them, however, were mainly on the lookout for a more positive Norwegian foreign policy, which they could find not just in opposing NATO expansion in the south of Europe or in a quest for a nuclear free Nordic zone, but also in the field of development aid. Natvig- Pedersen was an early aid enthusiast.

5 Haraldstad, H. (1994) Franco-Spain's greatest enemy? Norway's relations with Franco-Spain, 1946-1950. University of Oslo: Unpublished M. phil. thesis in history.

6 Christensen, Egil (1970) From unification dreams to normalcy. On the cooperation negotiations between the Labor Party and the Communists in 1945. University of Oslo: Unpublished M. phil. thesis in history.

\section{REFERENCES}

Benum, Edgeir (1969) Maktsentra og opposisjon [Power centers and opposition]. Universitetsforlaget, Oslo.

Bergh, Trond (1987) Storhetstid (1945-1965). Vol. 5 in History of the Norwegian Labor Movement. Tiden, Oslo.
Botero, Rodrigo (2001) Ambivalent Embrace. America's Troubled Relationship with Spain from the Revolutionary War to the Cold War. Greenwood Press, Westport.

Eriksen, Knut E. (1972) DNA og NATO [The Labor Party and NATO]. Gyldendal, Oslo.

Eriksen, Knut E. and Pharo, Helge Ø. (1997) Kald krig og internasjonalisering 1949-1965 [Cold War and internationalization 1949-1965]. Vol. 5 in History of Norwegian Foreign Relations. Universitetsforlaget, Oslo.

FRUS = Foreign Relations of the United States. (1945), 2; (1946), 5; (1947), 3; (1955-1957), 27.

Fure, Odd B. (1996) Mellomkrigstid 1920-1940 [The interwar years 1920-1940]. Vol. 3. in History of Norwegian Foreign Relations. Universitetsforlaget, Oslo.

Kvam, Ragnar Jr. (1973). DNA mot splittelse. Cappelen, Oslo.

Luard, Evan (1982). A History of the United Nations. Vol. 1. MacMillan, London.

Maurseth, Per (1987) Gjennom kriser til makt. 1920-1935. [Through crises to power. 1920-1935]. Vol. 3. in History of the Norwegian Labor Movement. Tiden, Oslo.

Mordt, Gerd (ed.) (2003) Arne Ordings dagbøker. Bind II [Arne Ording's diaries. Vol. II]. Universitetsforlaget, Oslo.

Pharo, Helge Ø. (1976). "Bridgebuilding and Reconstruction. Norway faces the Marshall Plan". Scandinavian Journal of History, I, 1-2: 125-53.

Pharo, Helge Ø. (1989) “Gjenreisning og utenrikspolitikk” [Reconstruction and foreign policy)]. In Historiker og veileder [Historian and guide], eds. Bergh, Trond and Pharo, Helge Ø. Oslo: Tiden.

Pharo, Helge Ø. (2004) "Post-Cold War Historiography in Norway". In The Cold War-and the Nordic Countries. Historiography at a Crossroads, ed. Olesen, Thorsten B. University of South Denmark Press, Odense.

Pharo, Helge Ø. (2005) "Den norske fredstradisjonen-et forskningsprosjekt" [The Norwegian peace tradition-a research project]. Historisk tidsskrift, 84, 2: 239-55.

Pharo, Helge Ø. (2014) "Gru og glede: Marshallplanen og Keralaprosjektet som merkesteiner i norsk historie" [Dread and Joy. The Marshall Plan and the Kerala Project as landmarks in Norwegian history]. In Politikk $i$ grenseland [Politics in a borderland], eds. Claes, Dag H.; Heidar, Knut and Holst, Cathrine. Universitetsforlaget, Oslo.

Pryser, Tore (1987) Klassen og nasjonen. 1935-1946 [Class and nation. 1935-1946]. Vol. 4 in History of the Norwegian Labor Movement. Tiden, Oslo.

Riste, Olav (1965) The Neutral Ally: Norway's Relations with the Belligerent Powers in the First World War. Oslo: Universitetsforlaget.

Riste, Olav (2005) Norway's Foreign Relations-A History. Oslo: Universitetsforlaget.

Russel, Ruth B. (1958) A History of the United Nations Charter. The Role of the United States 1940-1945. Brookings Institution, Washington, D.C.

Shipulina, Tatiana (2013) Et universelt FN? Norge og spørsmålet om medlemskap i FN for Spania, Kina og Korea [A universal United Nations. Norway and the issue of membership in the UN for Spain, China and Korea]. University of Oslo: Unpublished MA thesis in history.

Stenersen, Øivind (1991) "Venstrekreftene i norsk politikk 194565 " [The left in Norwegian politics 1945-65]. In Vekst og velstand edited by Bergh, Trond and Pharo, Helge $\varnothing$. [Growth and prosperity]. 3rd ed. Universitetsforlaget, Oslo.

Stortingsmelding [St.meld., parliamentary white paper], 12, (1947).

Stortingstidenede [St.t., parliamentary records] (1945-1946).

Sverdrup, Jakob (1996) Inn i storpolitikken 1940-1949 [Joining great power politics 1940-1949]. Vol. 4. in History of Norwegian Foreign Relations. Universitetsforlaget, Oslo. 